\title{
SEBARAN JENIS TENGKAWANG (Shorea Spp) di HUTAN TEMBAWANG DESA LABIAN KECAMATAN BATANG LUPAR KAPUAS HULU KALIMANTAN BARAT
}

\author{
(Distribution Of Species Tengkawang (Shorea spp) On Tembawang Forest Of Labian Village \\ Batang Lupar Sub District Kapuas Hulu West Kalimantan)
}

\author{
Riki Rikando, Siti Latifah , Togar Fernando Manurung \\ Fakultas Kehutanan Universitas Tanjungpura Pontianak. J1. Daya Nasional Pontianak 78124 \\ Email : rikirikardozx@gmail.com
}

\begin{abstract}
Kapuas Hulu Regency is lowland area of tropical rain forest which has many Dipterocarpaceae, one of which is tengkawang ( Shorea spp). Forests in Kapuas Hulu are currently under threat because of the widespread exploitation of land on a large scale without considering the balance of the ecosystem. Tembawang forest in Labian village has the potential of tengkawang trees which have not been known to be distributed based on topography where is grows. The aim of this study is to obtian the distribution of tengkawang (Shorea spp) species based on topography in the tembawang forest in the Labian district of Kapuas hulu, Kalimantan. This research was conducted using a survey method with samples taken in census in six tembawang. The research results show that there are 4 species of tengkawang (Shorea spp). The disribution of tengkawang spesies based on the from of thopography of Shorea marcophylla Aston and Shorea seminis Slooten grew on the topografhy of the valley with a height of $0-87$ meter above sea level and slope of $9 \%-23 \%$ in all tembawang spread in group closed to waterside and scattered clustered at the Shorea pinanga Scheff and Shorea stenoptera Bruck spread on slope in groups with a height of 60-70 meter above sea level.
\end{abstract}

Keywords : distributions, dipterocarpaceae, tembawang, tengkawang

\section{PENDAHULUAN}

Kapuas Hulu sebagian besar wilayahnya memiliki ketinggian antara 25 sampai 500 meter, sehingga tanaman yang banyak tumbuh di wilayah ini adalah tanaman-tanaman dataran rendah sub tropis dan tropis (RPJMD KH 2011). Sebagian kecil daerah perbukitan di sebelah Utara dan Timur gugusan Danau Luar di Kecamatan Batang Lupar memiliki ketinggian antara 100500 meter. Secara geografis, persebaran jenis Dipterocarpaceae tidak merata di wilayah Indonesia, berbeda dengan jenis suku lain misalnya Myrtaceae, Euphorbiaceae, Lauracaeae, Moraceae, dan Annoceae yang umumnya mempunyai persebaran luas (pantropis) (Bawa 1998) dalam Purwaningsih, 2004). Dipterocarpaceae di Indonesia tersebar tidak merata di setiap pulau, menurut Ashton (1982) bahwa penyebaran Dipterocarp ke arah timur kenekaragamannya semakin kecil. Secara ekologis jenis Dipterocarpaceae mempunyai beberapa faktor pembatas untuk pertumbuhan dan penyebarannya. Faktor yang paling menentukan adalah faktor tanah, iklim dan ketinggian tempat. Pada umumnya Dipterocarpaceae tumbuh pada jenis tanah podsolik merah kuning dengan 
ketinggian dibawah $1300 \mathrm{~m}$ dpl., dan curah hujan > $1000 \mathrm{~mm}$ per tahun (Whitmore1975) dalam (Purwaningsih, 2004).

Tengkawang (Shorea spp.) merupakan salah satu jenis tanaman kehutanan yang tumbuh di hutan hujan tropika. Keberadaan tengkawang di habitat alamanya saat ini mulai berkurang populasinya dan sulit ditemukan (Saridan et al. 2013). Kegunaan tengkawang sebagai salah satu jenis kayu primadona hutan tropika mulai sulit dicari di pasaran, ekploitasi terhadap jenis ini sangat besar sejalan dengan kebutuhan kayu yang meningkat. Kayu tengkawang terutama dipakai venir dan kayu lapis, selain itu kayu tengkawang juga dipakai untuk bangunan perumahan, kayu perkapalan, mabel, alat musik, dan peti pengepak (Istomo. 2010). Menurut Nuning S. Barwa (1997) kegunaan tengkawang yaitu sebagai pengganti lemak coklat, bahan komestik, bahan farmasi, margarin, liin dan sabun.

Tengkawang (Shorea spp.) merupakan salah satu jenis dari Famili Dipterocarpaceae yang tersebar pada kawasan hutan tembawang Desa Labian Kecamatan Batang Lupar Kabupaten Kapuas Hulu, dimana sampai saat ini belum ada data informasi mengenai persebaran berdasarkan tofografi (lembah, lereng, bukit) di sampaikan dalam peta untuk mendata sebaran tengkawang berdasarkan tingkat tumbuh pada setiap lokasi tembawang. Pentingnya mendata persebaran tengkawang pada setiap tembawang yang terdapat pada desa Labian, mengingat jenis dan potensinya dan kemungkinan untuk dilestarikan, dimanfaatkan dan dikembangkan atau dibudidayakan, maka dari itu perlu dilakukan penelitian tentang sebaran jenis tengkawang (Shorea spp.) pada hutan tembawang Desa Labian Kabupaten Kapuas Hulu.

Tujuan penelitian ini adalah untuk mendapatkan data sebaran jenis tengkawang berdasarkan topografi tempat tumbuh jenis tengkawang (Shorea spp) pada hutan tembawang Desa Labian. Manfaat penelitian ini yaitu sebagai informasi mengenai sebaran jenis tengkawang berdasarkan bentuk tofografi tempat tumbuh tengkawang, mulai dari kemiringan lokasi, dan ketingian tempat, sehingga dapat menjadi bahan dasar penelitian lanjutan dalam hal sebaran tempat tumbuh yang cocok untuk pohon tengkawang, serta untuk menambah wawasan ilmu pengetahuan tentang jenis dan sebaran tengkawang dalam rangka upaya pengelolan, konservasi dan pelestarian jenis tengkawang.

\section{METODE PENELITIAN}

Penelitian ini dilaksanakan pada 6 hutan tembawang Desa Labian yaitu Tembawang Kayu Baung, Tembawang Kelakar, Tembawang Angat, Tembawang Lucak Tembawang Gindoh dan Tembawang Buban Kecamatan Batang Lupar, Kabupaten Kapuas Hulu Kalimantan Barat. Pelaksanaan penelitian dilakukan selama 4 minggu dari tanggal 1-31 Agustus 2018 di lapangan. Alat yang digunakan dalam 
penelitian ini yaitu peta lokasi penelitian, kompas, GPS (Global Potisioning system), Phiband, cat, Klinometer, Kamera, Kalkulator, buku identifikasi jenis tengkawang, Thally Sheet, alat herbarium (koran, pisau cutter, isolasi, label dan plastik) sedangkan objek penelitian ini yaitu semua jenis tengkawang. Penelitian ini dilakukan dengan metode survei dengan pengambilan data secara sensus diawali dengan membuat jalur transek yang memotong garis kontur dan merupakan garis terpanjang dengan menggunakan sofwer ArcGis 10.1 yang kemudian digunakan sebagai sumbu utama selanjutnya membuat garis tegak lurus sumbu utama dengan lebar $20 \mathrm{~m}$. Kemudian dilakukan pembuatan plot pengamatan di dalam jalur pengamatan. Dalam masing-masing petak tersebut dibuat sub petak contoh ukuran $2 \mathrm{~m} x$ $2 \mathrm{~m}$ untuk tingkat semai, petak ukuran $5 \mathrm{mx} 5 \mathrm{~m}$ untuk tingkat pancang, petak ukuran 10mx10m digunakan untuk pengamatan tingkat tiang dan petak ukuran 20mx20m digunakan untuk pengamatan tingkat pohon (Soerianegara dan Indrawan, 1982 in Indriyanto, 2006).

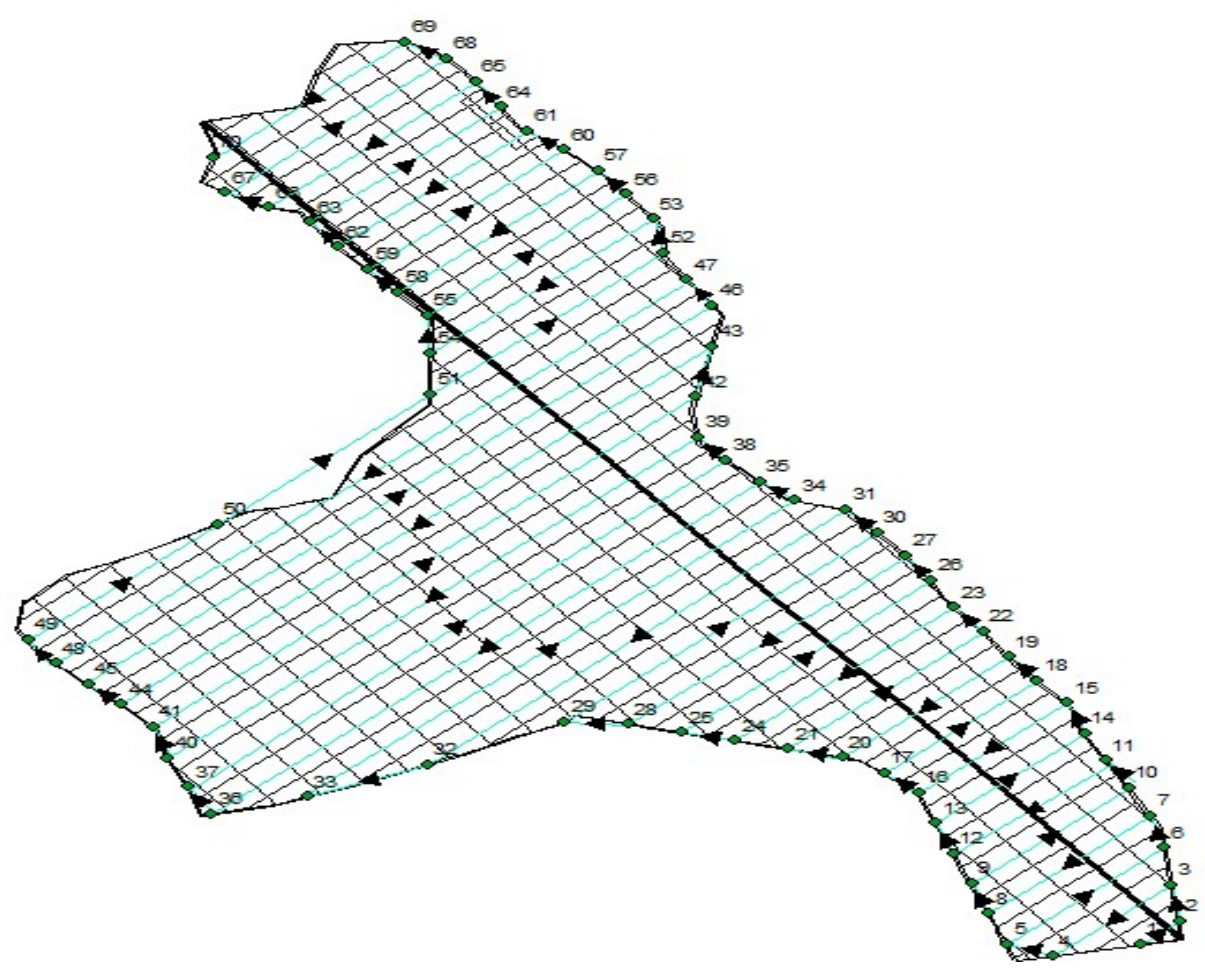

Gambar 1. Contoh Desain jalur transek penelitian tembawang Kayu Baung (Examples of transeklines of Research Design tembawang Kayu Baung) 
Vol. 7 (1) : 390 - 406

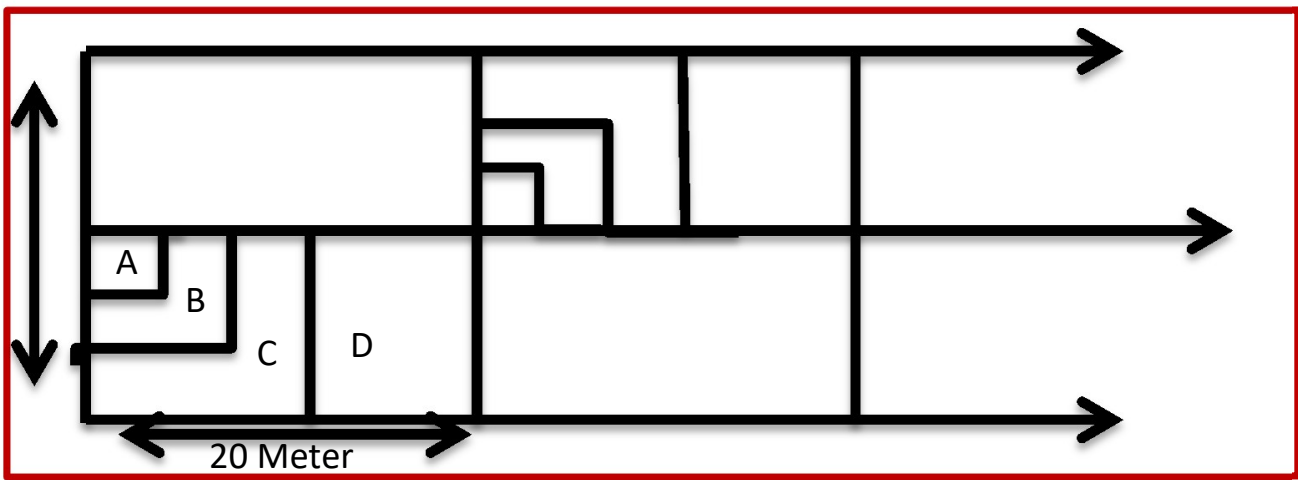

Gambar 2. Contoh desain jalur pengamatan (Example design line observations)

Keterangan :

A : Petak pengamatan ukuran $2 \mathrm{~m} \times 2 \mathrm{~m}$ (tingkat semai)

$B$ : Petak pengaamatan ukuran $5 \mathrm{~m} \times 5 \mathrm{~m}$ ( tingkat pancang)

$C$ : Petak pengamatan ukuran $10 \mathrm{~m} \times 10 \mathrm{~m}$ (tingkat tiang)

D : Petak pengamatan ukuran $20 \mathrm{~m} \times 20 \mathrm{~m}$ (tingkat pohon)

Pengambilan data dilakukan dengan menggunakan GPS (Garmin GPSmap78s), setiap jenis pohon tengkawang yang ditemukan di dalam kawasan hutan tembawang diambil titik koordinat beserta nama lokalnya, setiap pohon tengkawang yang sudah diambil titik koordinatnya (marking point) diberi tanda dengan pita penanda, kemudian diukur dengan phiband guna mengambil data diameternya. Dilakukan pengukuran data ketinggian tempat (elevasi), kelerengan (slope) dan arah kelerengan yang ditumbuhi pohon tengkawang. Hasil pengambilan data yang diperoleh disalin ke tally sheet. Analisi dilakukan dengan analisis deskriptif.

\section{HASIL DAN PEMBAHASAN}

Berdasarkan hasil survey di hutan tembawang Desa Labian terdapat empat jenis tengkawang, tengkawang Amat (Shorea macrophylla P.S. Ashton), tengkawang Langgai (Shorea pinanga Scheff), tengkawang Tukul (Shorea stenoptera Bruck) dan tengkawang Breh (Shorea seminis Slooten). Rekapitulasi jenis dan jumlah pada masing-masing tembawang dapat dilihat pada Tabel 1 . 
Tabel 1. Jenis dan Jumlah Pada Masing-masing Tembawang (Type and quantity of each Tembawang)

\begin{tabular}{|c|c|c|c|c|c|c|c|}
\hline & Jenis & $\begin{array}{l}\mathrm{Se} \\
\mathrm{mai} \\
\text { (ha) }\end{array}$ & $\begin{array}{l}\text { Pancan } \\
\text { g (ha) }\end{array}$ & $\begin{array}{c}\text { Tian } \\
\text { g } \\
\text { (ha) }\end{array}$ & $\begin{array}{l}\text { Poho } \\
\text { n (ha) }\end{array}$ & $\begin{array}{l}\text { Kelerenga } \\
\mathrm{n}\end{array}$ & $\begin{array}{l}\text { Ketinggian } \\
\mathrm{M} \text { dpl }\end{array}$ \\
\hline $\begin{array}{c}\text { TK } \\
\mathrm{B}\end{array}$ & $\begin{array}{l}\text { Shorea } \\
\text { macrophylla } \\
\text { Shorea stenoptera } \\
\text { Shorea pinanga }\end{array}$ & $\begin{array}{r}100 \\
73 \\
91 \\
\end{array}$ & $\begin{array}{c}12 \\
1 \\
0 \\
\end{array}$ & $\begin{array}{l}3 \\
0 \\
0\end{array}$ & $\begin{array}{c}5 \\
0,18 \\
0,27\end{array}$ & $9 \%$ & $40-63$ \\
\hline TK & $\begin{array}{l}\text { Shorea } \\
\text { macrophylla } \\
\text { Shorea seminis } \\
\text { Shorea pinanga }\end{array}$ & $\begin{array}{r}546 \\
29 \\
0 \\
\end{array}$ & $\begin{array}{c}5 \\
0,93 \\
0 \\
\end{array}$ & $\begin{array}{c}0,6 \\
0,23 \\
0,23 \\
\end{array}$ & $\begin{array}{c}1 \\
0,1 \\
0 \\
\end{array}$ & $9 \%$ & $40-69$ \\
\hline TL & $\begin{array}{l}\text { Shorea } \\
\text { macrophylla }\end{array}$ & 75 & 20 & 9 & 6 & $9 \%$ & $40-59$ \\
\hline TA & $\begin{array}{l}\text { Shorea } \\
\text { macrophylla }\end{array}$ & 409 & 38 & 3 & 4 & $9 \%$ & $40-77$ \\
\hline TB & $\begin{array}{l}\text { Shorea } \\
\text { macrophylla }\end{array}$ & 104 & 11 & 3 & 2 & $\begin{array}{l}23,50 \\
\%\end{array}$ & $58-60$ \\
\hline $\mathrm{TG}$ & $\begin{array}{l}\text { Shorea } \\
\text { macrophylla }\end{array}$ & $\begin{array}{r}2.67 \\
8 \\
\end{array}$ & 25 & 6 & 11 & $\begin{array}{ll} & 23,50 \\
\% & \\
\end{array}$ & $41-84$ \\
\hline
\end{tabular}

Berdasarkan hasil data rekapitulasi menunjukan jenis dan jumlah individu tengkawang mulai dari tingkat pohon, tiang, pancang, dan semai yang terdapat pada hutan tembawang desa Labian. Tembawang Kayu Baung (12 ha) merupakan lokasi dengan jumlah jenis tengkawang terbanyak, ditemukan 3 jenis tengkawang yaitu tengkawang Amat (Shorea macrophylla P.S.Ashton) pada tingkat semai 100 individu per ha, tingkat pancang terdapat 12 individu per ha, tiang terdapat 3 individu per ha dan tingkat pohon terdapat 5 individu per ha. Shorea macrophylla P.S.Ashton pada tingkat pohon paling banyak jumlahnya di tembawang Kayu Baung, lebih banyak dari tingkat semai dikarenakan lokasi tembawang Kayu Baung dekat dengan pemukiman sehingga buah yang jatuh akan diambil oleh masyarakat pada saat musim berbuah. Tengkawang Tukul (Shorea stenoptera Bruck) pada tingkat semai terdapat 73 individu per ha, tingkat pancang 1 individu per ha, tingkat pohon terdapat 0,18 individu per ha. Tengkawang Langgai (Shorea pinanga Scheff) berdasarkan hasil survei hanya ditemukan pada tingkat semai dan tingkat pohon, 91 individu per ha tingkat semai dan 0,27 individu per ha tingkat pohon.

Tembawang Kelakar ditemukan jenis Shorea macrophylla P.S.Ashton, Shorea seminis Slooten dan Shorea pinanga Scheff. Shorea macrophylla P.S.Ashton pada tingkat semai terdapat 546 semai per ha, untuk pertumbuhan tingkat pancang terdapat 5 individu per ha di tembawang Kelakar, pertumbuhan tingkat tiang terdapat 0,6 individu per ha dan pertumbuhan tingkat pohon terdapat 1 individu per 
ha. Engkabang Breh (Shorea seminis Slooten) dengan jumlah tingkat semai 29 individu per ha, tingkat pancang terdapat 0,93 individu per ha, tingkat tiang terdapat 0,23 individu per ha di tembawang Kelakar dan tingkat pertumbuhan pohon terdapat 0,1 individu per ha di tembawang Kelakar. Jenis tengkawang Langgai (Shorea pinanga Scheff) ditemukan hanya pada tingkat pertumbuhan tiang dengan 0,23 individu per ha pada tembawang Kelakar.

Berdasarkan hasil survei di tembawang Lucak (4,5 ha) berdasarkan hasil survey hanya dijumpai satu jenis yaitu Shorea macrophylla P.S.Ashton, pada tingkat pertumbuhan semai ditemukan 75 individu per ha, untuk pertumbuhan tingkat pancang ditemukan 20 individu per ha, pertumbuhan tingkat tiang ditemukan 9 individu per ha dan pertumbuhan tingkat pohon ditemukan 6 individu per ha di tembawang Lucak. Pertumbuhan tingkat semai sedikit ditemukan pada tembawang Lucak dikarenakan lokasi tembawang ini dekat dari perkampungan dan pada musim berbuah banyak dipungut oleh masayarakat sekitar sehingga sedikit buah tengkawang yang bisa tumbuh secara alami.

Berdasarkan hasil survey tembawang Angat (4,9 ha) dijumpai satu jenis tengkawang (Shorea macrophylla P.S.Ashton) dengan jumlah pada pertumbuhan tingkat semai 409 individu per ha, untuk pertumbuhan tingkat pancang terdapat 38 individu per ha, pertumbuhan tingkat tiang terdapat 3 individu per ha, dan tingkat pohon terdapat 4 individu per ha. Pada tembawang ini berlokasi dekat dengan perkampungan sehingga pada saat musim berbuah buah tengkawang yang jatuh akan dipungut oleh masyarakat sekitar sehingga mengurangi regenerasi tengkawang secara alami. Pertumbuahan tingkat pohon dan anakan masih tergolong baik dan terjaga keletariannya.

Berdasarkan hasil survei tembawang Buban (2,5 ha) hanya terdapat tengkawang Amat (Shorea macrophylla P.S.Ashton) pada tingkat semai terdapat 104 individu per ha, tingkat pancang terdapat 11 individu per ha, untuk tingkat tiang terdapat 3 individu per ha, dan tingkat pohon terdapat 2 individu per ha. Tembawang Buban hanya sedikit saja ditumbuhi oleh Shorea macrophylla P.S.Ashton hal ini dikarenakan topografi tembawang Buban termasuk landai dengan kelas lereng $11 \%$ sehingga regenerassi akan terhambat, selain itu terdapat faktor lain dari makhluk hidup seperti babi hutan dan masyarakat akan mengambil buah yang jatuh ke permukaan tanah.

Berdasarkan hasil survei di tembawang Gindoh (6 ha) hanya dijumpai tengkawang Shorea macrophylla P.S.Ashton, pada tingkat semai terdapat 2.678 individu per ha, tingkat pertumbuhan pancang terdapat 25 individu per ha, tingkat pertumbuhan tiang terdapat 6 individu per ha dan pertumbuhan tingkat pohon dijumpai 11 individu per ha. Tembawang Gindoh 
merupakan lokasi Shorea macrophylla P.S.Ashton terbanyak dikarenakan berbagai faktor lokasi tembawang yang jauh dari permukiman sehingga pada musim berbuah jarang diambil oleh masyarakat setempat, jadi buah yang jatuh akan banyak berkecambah dan tumbuh secara alami, tembawang Gindoh merupakan lokasi yang cocok untuk Shorea macrophylla P.S.Ashton untuk tumbuh secara regenerasi alam.
Shorea macrophylla P.S.Ashton di hutan tembawang Kayu Baung terdapat ketidakseimbangan antara jumlah sebaran pohon dengan anakan, jumlah anakan lebih sedikit dibandingkan pohon induk. Hal tersebut didasarkan pada masalah di lapangan yaitu pada musim berbuah dan jatuh ke tanah maka buah tersebut akan diambil masyarakat dan tidak sempat berkecambah. Lokasi masing-masing tembawang di Desa Labian dapat dilihat pada Gambar 3.

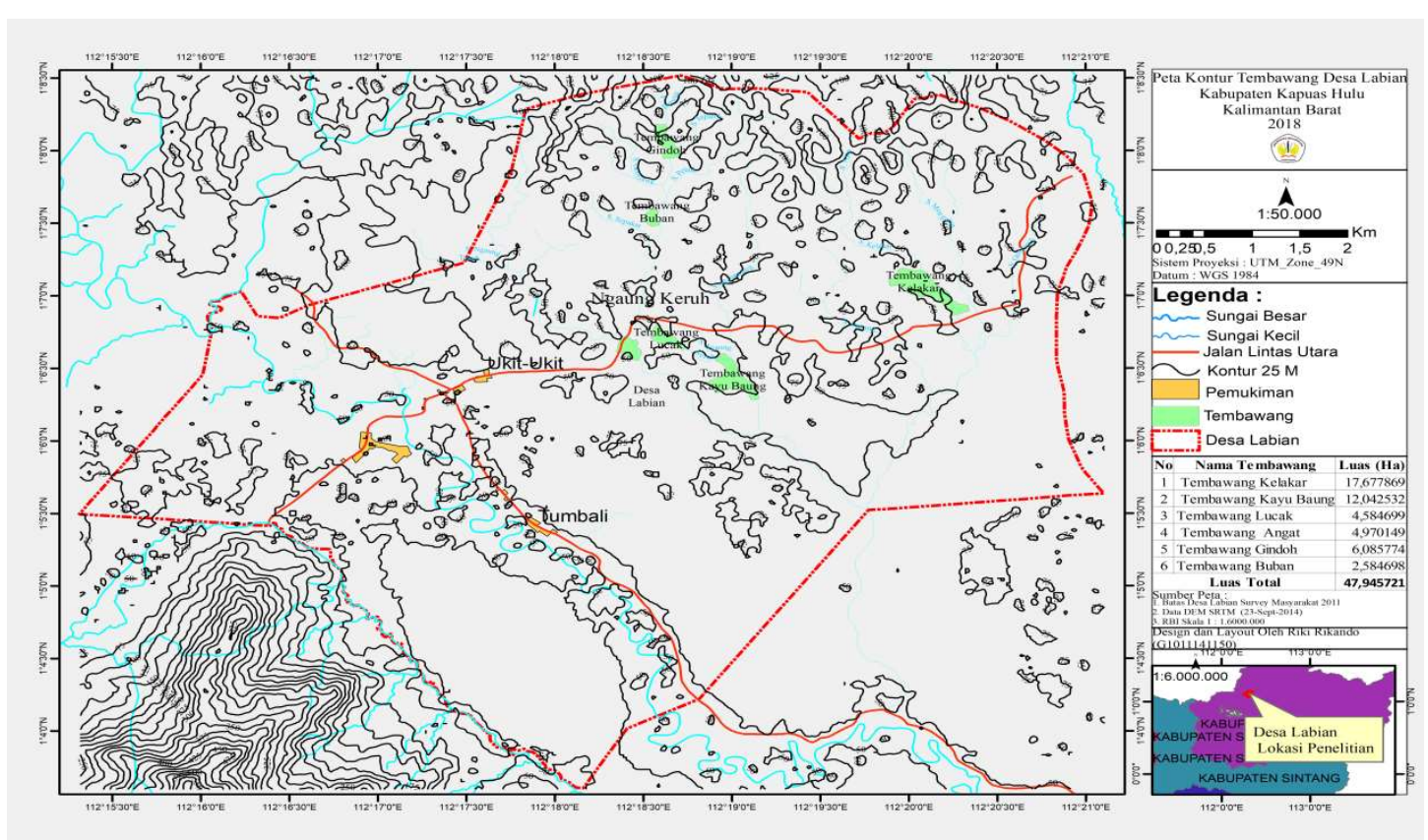

Gambar 3. Peta Lokasi Sebaran Tembawang di Desa Labian (Location map of the distribution of Tembawang in the village of Labian)

\section{Sebaran Tengkawang}

Sebaran jenis tengkawang berdasarkan tingkat pertumbuhan dan topografi mulai dari lembah seperti dataran yang dekat dengan tepi sungai dan terdapat juga pada lereng atau pada kaki bukit. Rekapitulasi data sebaran jenis tengkawang dan sebaran berdasarkan topografi dapat dilihat pada Tabel 2. 
Tabel 2. Sebaran Tengkawang Berdasarkan Tingkat Pertumbuhan dan Topografi (Tengkawang distribution based on the growth rate and topography)

\begin{tabular}{lcccc}
\hline \multirow{2}{*}{ Jenis } & \multicolumn{4}{c}{ Tingkat Pertumbuhan } \\
\cline { 2 - 5 } & Semai & Pancang & Tiang & Pohon \\
\hline Shorea macrophylla A & & & & \\
Lembah & 209 & 36 & 33 & 158 \\
Lereng & 71 & 4 & 3 & 31 \\
\hline Shorea stenoptera $\mathrm{B}$ & & - & - & 2 \\
Lereng & 8 & 1 & - & 3 \\
\hline Shorea pinanga Sc & 10 & 1 & 1 & 2 \\
Lereng & 5 & & & \\
\hline Shorea seminis Sl & & & & \\
Lembah & & &
\end{tabular}

Sumber: Diolah dari data primer

Berdasarkan Tabel 2 menunjukkan bahwa sebaran jenis Shorea macrophylla P.S.Ashton paling banyak ditemukan pada topografi lembah dan lereng, ternyata pada topografi lembah paling banyak ditemukan sebaran tengkawang jenis Shorea macrophylla P.S.Ashton, tingkat semai 209 individu dan tingkat pancang sebanyak 36 individu, tingkat tiang 33 dan tingkat pohon ditemukan 158 individu. Shorea stenoptera Bruck hanya ditemukan pada topografi lereng yaitu pada tingkat semai 8 individu dan pertumbuhan tingkat pohon 2 individu. Shorea pinanga Scheff tersebar pada topografi lereng ditemukan tingkat semai 10 individu, tingkat pancang 1 individu dan tingkat pohon 3 individu. Shorea seminis Slooten persebarannya terdapat pada topografi lembah pada tingkat semai ditemukan 5 individu, pada tingkat pancang ditemukan 1 individu, tingkat tiang ditemukan 1 individu dan tingkat pohon sebanyak 2 individu. Shorea macrophylla P.S.Ashton ditemukan pada lembah untuk semua tingkat pertumbuhan dari
436 individu terdapat $48 \%$ pada tingkat semai menandakan masih bisa beregenerasi secara alam dan cocok tumbuh pada topografi lembah dengan kelas lereng yang datar sampai landai bergelombang.

Persebaran tengkawang jenis Shorea macrophylla P.S.Ashton yang paling banyak tersebar tumbuh pada topografi lembah atau dekat dengan pinggiran sungai. Sesuai dengan penelitian Supartini (2015) mengatakan jenis Shorea macrophylla P.S.Ashton dominan ditemukan pada topografi lembah, pohon tengkawang di lembah memiliki luas bidang dasar dan volume lebih besar dibandingkan dengan pohon tengkawang yang berada di bukit dengan hasil penelitian persebaran pohon tengkawang selalu ditemukan pada topografi lembah. Hal ini juga sama terjadi dengan keadaan topografi tersebarnya tengkawang di enam hutan tembawang Desa Labian rata-rata lokasi tempat tumbuh di lewati oleh sungai dari perhuluan sampai hilir. 
Jika dilihat dari tabel 2 sebaran tengkawang dari semua tingkat pertumbuhan secara keseluruhan di enam tembawang Desa Labian jumlah tersebut masih relatif seimbang sebarannya, adapun terdapat anakan yang tidak seimbang dengan induknya disebabkan oleh masyarakat yang mengambil habis buah yang jatuh ke permukaan tanah pada saat tengkawang musim berbuah, sehingga buah yang jatuh tidak sempat untuk berkecambah dan tumbuh di hutan tembawang di Desa Labian.

\section{Sebaran Tengkawang di Tembawang} Kayu Baung

Sebaran jenis tengkawaang yang terdapat pada hutan tembawang Kayu Baung yaitu Engkabang Amat (Shorea macrophylla P.S.Ashton), Engkabang Tukul (Shorea stenoptera Bruck), dan Engkabang Langgai (Shrea pinanga Scheff). Jenis Shorea macrophylla P.S.Ashton pada tingkat pohon yang paling banyak penyebarannya hampir di sepanjang hutan tembawang dekat dengan sungai dan tempat yang lembab dengan ketinggian 40 - 63 mdpl. Penyebaran Shorea macrophylla ditemukan di dekat sungai dikarenakan peran air yang membawa buah yang jatuh ke sungai akan hanyut dan tumbuh di perhiliran dekat tepian sungai. Tembawang Kayu Baung secara topografi mempunyai bentuk lahan yang datar, landai dan sedikit berlereng, tengkawang Shorea macrophylla P.S.Ashton sangat banyak terdapat di lembah dan tempat yang datar dekat sungai hanya sedikit yang tumbuh di lereng. Persebaran jenis ini dipengaruhi oleh bentuk tajuk pohon induk yang tidak lebar dan tumbuh di lereng sehingga penyebaran anakan dengan pohon induk tidak akan jauh dan akan membentuk persebaran secara mengelompok. Jenis Shorea stenoptera Bruck dan Shorea pinanga Scheff pada tembawang Kayu Baung tumbuh pada lereng bukit dengan kemiringan antara 5 $\% \quad-\quad 9 \%$ termasuk landai dengan kemiringan sedikit. Sebagaimana menurut Purwaningsih (2004) jenis Dipterocarpaceae sebagian besar tumbuh di daerah lereng dan punggung bukit. Pola sebaran tegkawang dengan mengelompok baik tingkat semai, pancang, tiang maupun tingkat pohon. 

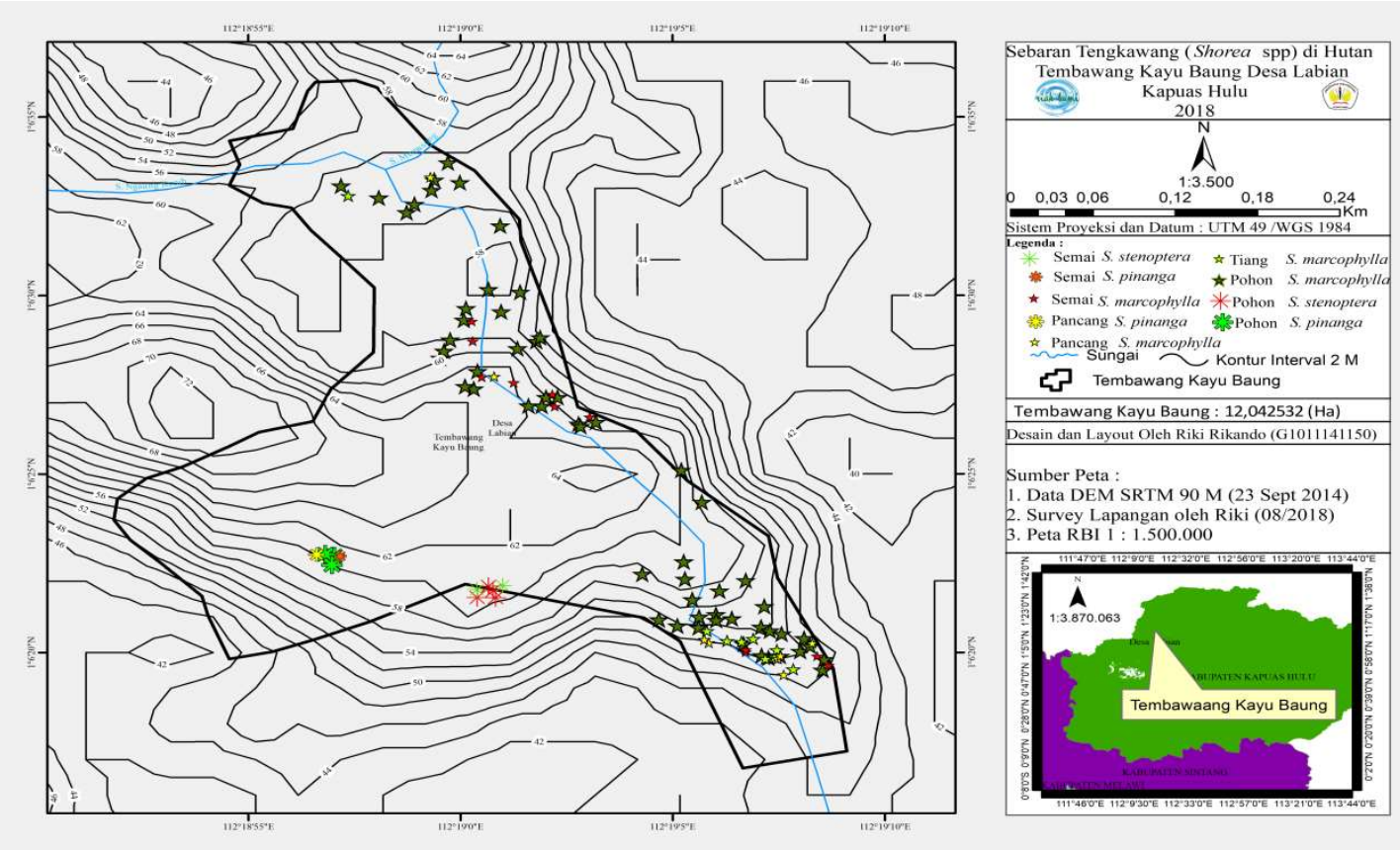

Gambar 4. Sebaran Tengkawang (Shorea spp) pada hutan tembawang Kayu Baung (Tengkawang distribution (Shorea spp) on forests tembawang Kayu Baung)

Pola penyerbaran 3 jenis tengkawang yang ditemukan pada tembawang kayu baung pada umunya mengelompok bila dilihat dari hasil analisis pemetaan (Gambar 4). Hal ini juga sama dengan hasil penelitian Istomo (2010) apabila sekitar lokasi induk jenis tumbuhan menyediakan hara yang cukup untuk pertumbuhan, maka akan cenderung berbentuk pola penyebaran tengkawang yang mengelompok. Lebih lanjut lagi Vebri (2017) melaporkan bahwa distribusi penyebaran untuk tingkat semai, pancang, tiang yaitu secara beraturan dan tingkat pohon penyebarannya berkelompok. Penyebaran berkelompok terjadi karena dipengaruhi oleh faktor lingkungan yang tergolong sebagai faktor bioekologi pada masaing-masing ketinggian. Indriyanto (2006) menyatakan distribusi berkelompok pada suatu populasi merupakan distribusi yang umum terjadi di alam, baik bagi tumbuhan maupun bagi hewan. Selain itu pola penyebaran berhubungan pula dengan faktor bioekologi yang memberikan pengaruh pada individu yang diteliti. Faktor bioekologi secara umum terbagi atas dua yakni faktor fisik atau abiotik yang terdiri atas faktor-faktor lingkungan yang bersifat non biologis seperti iklim (suhu udara, kelembaban udara, intensitas cahaya), tanah dan kondisi fisik lingkungan lainnya.

\section{Sebaran Tengkawang di Tembawang Kelakar}

Sebaran jenis tengkawang pada peta tembawang Kelakar menunjukan persebaran yang mengelompok yaitu terdapat jenis Shorea macrophylla P.S.Ashton yang dominan pada tingkat pohon sebesar 89,47\% (dari total pohon 
19) dan semai (Gambar 5). Kondisi tembawang Kelakar mempunyai topografi yang landai dan dekat dengan sugai merupakan habitat tengkawang yang paling banyak ditemui pada lokasi ini, dimana tembawang Kelakar tergolong dataran rendah dengan kelas lereng yaitu $9 \%$ landai. Tengkawang Breh (Shorea seminis Slooten) hanya beberapa pohon sekitar 10,52\% (dari total 19 pohon) dan anakan tumbuh secara mengelompok dan dekat dengan tepi sungai. Bentuk lahan yang datar sampai landai dekat dengan sungai banyak jenis Shorea macrophylla P.S.Ashton dan Shorea pinanga Scheff dan Shorea seminis Slooten hanya sedikit saja ditemukan. Pada kawasan hutan tembawang Kelakar Tengkawang tubuh di ketinggian mulai dari $40-69$ mdpl, dengan aspek lereng tempat tumbuh tengkawang lebih banyak menghadap ke timur laut seperti pada hal lokasi tembawang yang lain.

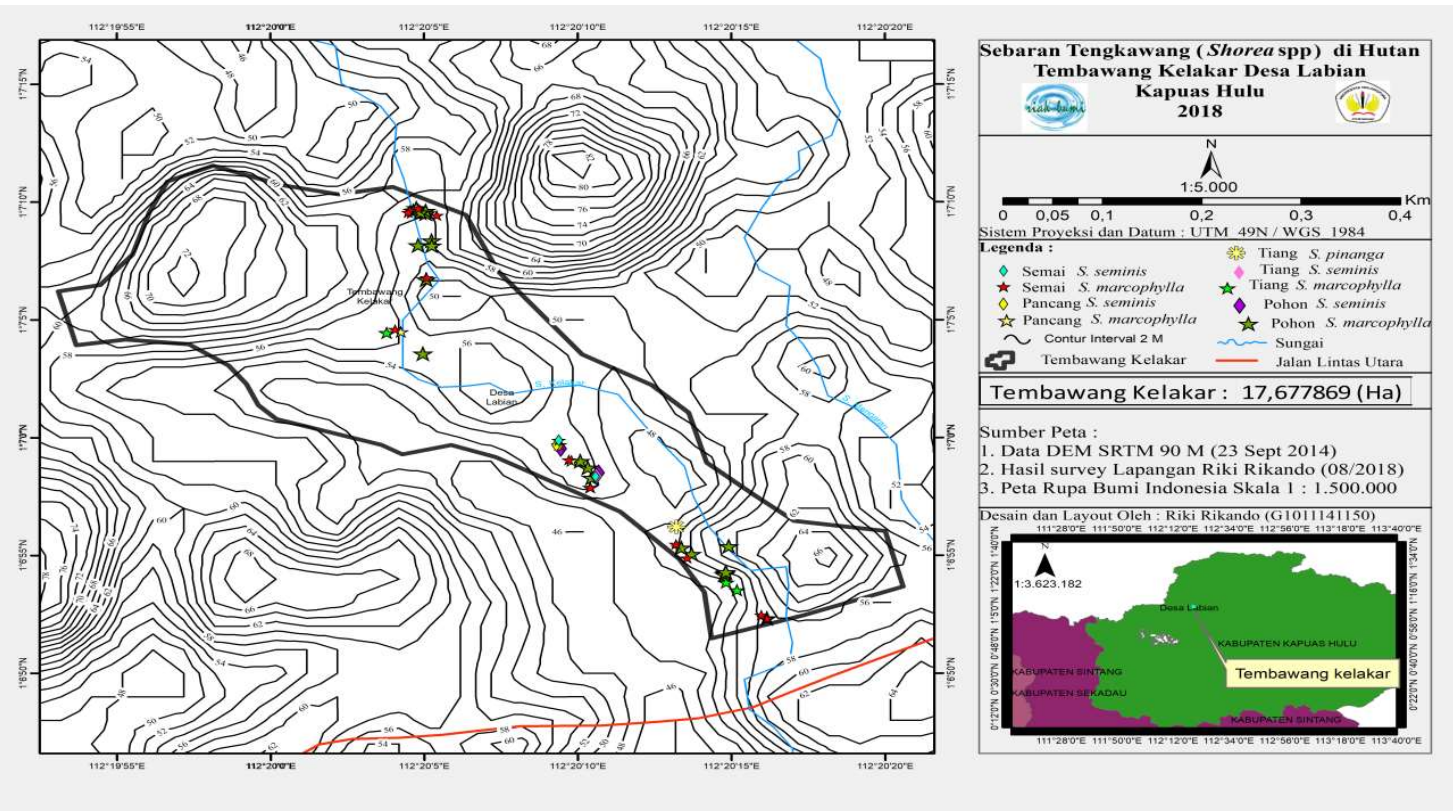

Gambar 5. Sebaran tengkawang (Shorea spp) pada hutan tembawang Kelakar (Tengkawang distribution (Shorea spp) on forest tembawang Kelakar)

Sebaran tengkawang di hutan tembawang ini termasuk lebih baik bila dibandingkan dengan tembawang Kayu Baung, hal ini dapat dibuktikan jumlah sebaran anakan sebanding dengan induknya, artinya tengkawang di tembawang Kelakar lebih terjaga anakan yang jatuh ke tanah dan tidak semua diambil oleh masayarakat sekitar dan hanya sebagian sedikit buah yang jatuh dimakan hewan, sehingga tengkawang bisa berkembangbiak secara baik di hutan tembawag Kelakar. Hasil penelitian juga membuktikan bahwa tengkawang banyak ditemukan tumbuh di lokasi tembawang yang dilewati oleh sungai seperti tembawang Kelakar yang hampir sebagian besar dilewati oleh sungai. Tengkawang yang mendominasi tembawang Kelakar yaitu Shorea macrophylla P.S. Ashton ditemukan hampir di seluruh lokasi hutan tembawang. 


\section{Sebaran Tengkawang di Tembawang Lucak dan Angat}

Tembawang Lucak ditemukan Engkabang Amat (Shorea macrophylla P.S.Ashton) sebaran pada tingkat pohon lebih banyak ditemukan daripada tingkat tiang, pancang dan semai. Penyebaran Shorea macrophylla P.S.Ashton di hutan tembawang Lucak ditemukan tumbuh secara berkelompok dan dekat dengan tepi sungai (Gambar 6). Aspek lereng tempat tumbuh tengkawang pada tembawang Lucak yaitu barat daya dengan kelerengan lereng yang termasuk landai di kelas lereng rata-rata $9 \%$ dengan ketinggian lokasi 40 - 59 mdpl . Sebaran tengkawang di hutan tembawang Lucak antara anakan dan tingkat pohon tidak sebanding jumlahnya dimana anakan lebih sedikit dari indukannya disebabkan lokasi tembawang yang sangat dekat dengan permukiman masyarakat dengan jarak sekitar 300 meter maka disetiap musim berbuah tengkawang yang jatuh ke permukaan tanah akan diambil habis oleh masyarakat sekitar. Lokasi tembawang merupakan milik umum masayarakat setempat. Sebaran tengkawang di tembawang Lucak juga ternyata ditemukan dengan kondisi lokasi tembawang yang dilewati oleh sungai.

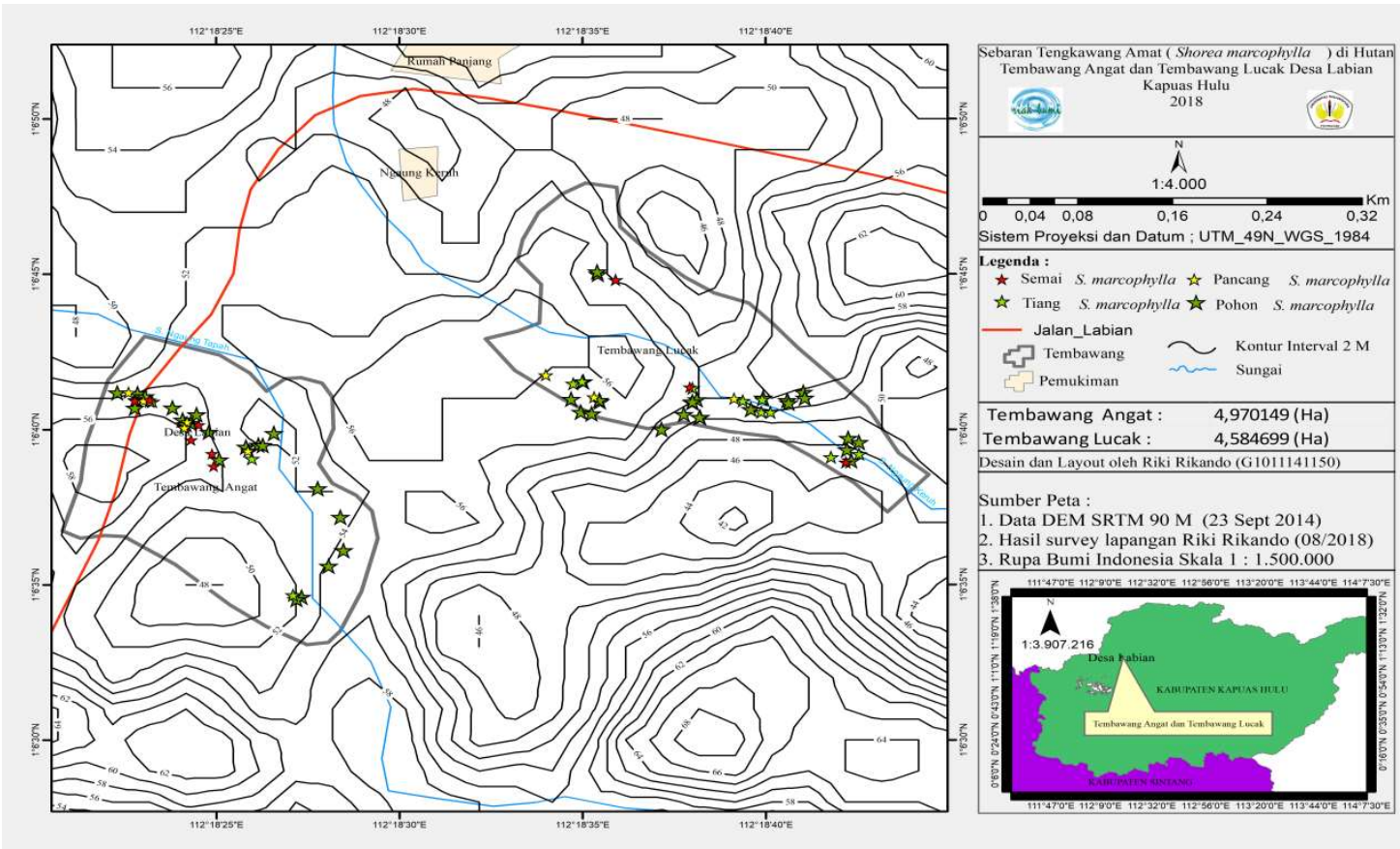

Gambar 6. Peta sebaran tengkawang (Shorea spp) pada hutan tembawang Lucak dan tembawang Angat (Map of the spread of tengkawang (Shorea spp) in the forest of tembawang and tembawang Lucak Angat)

Tembawang Angat juga didominasi oleh Engkabang Amat (Shorea macrophylla P.S.Ashton) tingkat pohon tersebar secara berkelompok dan yang paling banyak ditemukan. Anakan seperti semai tiang dan pancang juga sersebar tidak jauh dari pohon yang tersebar secara berkelompok sepanjang 
tepi sungai. Aspek lereng tempat tumbuh tengkawang pada tembawang Angat yaitu timur laut dengan kelerengan lereng termasuk landai dengan rata-rata kelas kereng $9 \%$ pada ketinggian lokasi $40 \quad-77$ mdpl. Tembawang Angat juga mempunyai sebaran anakan tidak sebanding dengan induknya dimana pertumbuhan tingkat pohon lebih banyak daripada tingkat anakan, hal ini disebabkan buah tengkawang yang jatuh kepermukaan tanah pada saat musim berbuah diambil oleh masayarakat sekitar sehingga untuk anakan tengkawang tidak sempat untuk berkecambah. Hal ini juga disebabkan letak dan lokasi tembawang Angat yang dekat dengan pemukiman masyarakat. Sama halnya dengan keadaan tembawang lain, tembawang Angat juga dilewati oleh sungai yang dimana banyak terdapat sebaran tengkawang yang ditemukan.

\section{Sebaran Tengkawang di Tembawang Buban}

Sebaran tengkawang ( Shorea Spp) pada hutan tembawag Buban terdapat satu jenis tengkawang yaitu Engkabang Amat ( Shorea macrophylla P.S.Ashton) tersebar hanya pada bagian tenggara tembawang Buban, pola sebaran tengkawang di tembawang Buban (Gambar 7) tersebar secara berkelompok dekat sungai dengan tempat tumbuh pada ketinggian $58-60$ mdpl dan dengan kemiliringan lereng $11 \%$ termasuk agak landai. Tembawang Buban terdapat sedikit tengkawang bila dibandingkan dari tembawang lain yang ada di desa Labian, hal ini dikarenakan pertumbuhan secara regenerasi alamnya tidak berjalan dengan baik, hal ini didukung pada musim tengkawang berbuah dan jatuh ke tanah akan rentan diambil masyarakat atau pun hewan seperti babi hutan.

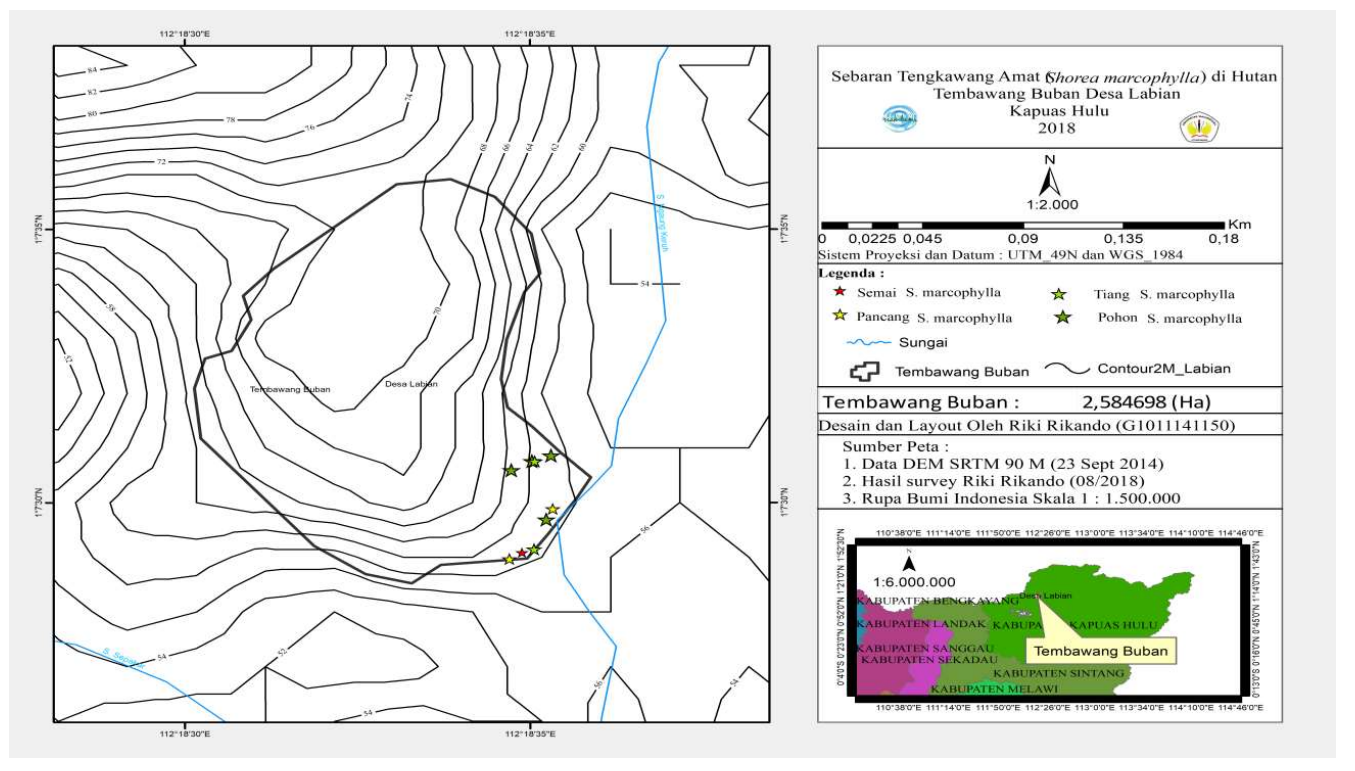

Gambar 7. Peta sebaran tengkawang (Shorea spp) pada hutan tembawang Buban (Map of the spread of tengkawang (Shorea spp) on forest tembawang Buban) 
Tembawang Buban merupakan tembawang yang memiliki sebaran tingkat pertumbuhan yang tidak seimbang antara jumlah anakan dengan tingkat pohon yang lebih sedikit, hal ini dikarenkan lokasi tembawang yang mudah dijangkau oleh masyarakat sekitar untuk mengambil buah yang jatuh pada musim berbuah. Tembawang Buban tidak langsung dilewati oleh sungai yang menjadi pembeda dengan tembawang yang lainnya, sehingga untuk sebaran tengkawang juga tidak banyak di temukan di tembawang Buban. Tembawang buban juga hanya terdapat satu jenis tengkawang yang ditemukan yaitu Shorea macrophylla P.S. Ashton.

\section{Sebaran Tengkawang di Tembawang Gindoh}

Tengkawang yang terdapat pada tembawang Gidoh dapat dilihat di (Gambar 8) tersebar secara berkelompok baik tingkat pohon, tiang, pancang dan semai. Tengkawang Amat (Shorea spp) tumbuh pada tembawang Gindoh merupakan hasil di tanam oleh warga tembawang pada saat mendiami tembawang Buban. Shorea macrophylla P.S.Ashton yang ditemukan tingkat pohon tumbuh pada kaki bukit ada kemiringan lereng rata-rata 23,5 \% termasuk agak curam, aspek lereng yang ditumbuhi tengkawang Shorea marcophylla P.S.Ashton lebih banyak menghadap ke timur laut (TL). Ketinggian tempat tumbuh tengkawang pada tembawang gindoh yaitu $41-84$ mdpl.

Persebaran tingkat semai Shorea macrophylla P.S.Ashton ditemukan paling banyak dikarenakan lokasi tembawang Gindoh yang jauh dari perkampungan warga sehingga pada musim berbuah buah tidak di ambil masyarakat mengingat jarak tempuh yang jauh dan status tembawang ini yiatu milik pribadi dan bukan umum sehingga ini juga menyebabkan tidak semua masayarakat mengambil buah yang jatuh ke permukaan tanah pada musim berbuah atau panen. Pola persebaran tengkawang pada teembawang Gindoh tumbuh secara berkelompok, anakan juga tidak jauh dari pohon induk. Lokasi tembawang Gindoh ternyata juga dilewati sungai secara langsung yang merupakan tempat pertumbuhan tengkawang paling banyak ditemukan hampir semua tembawang di Desa Labian. 

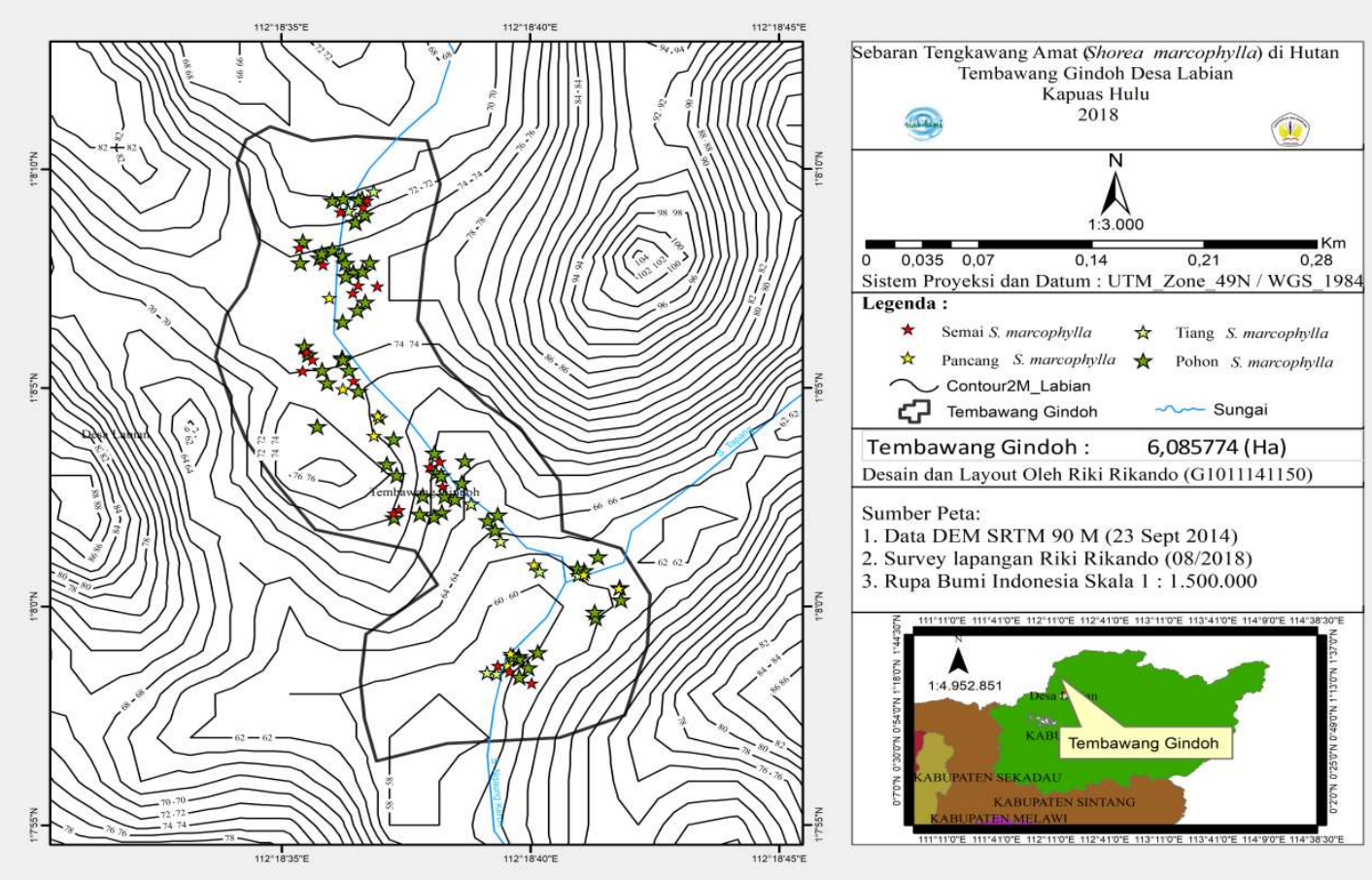

Gambar 8. Sebaran tengkawang (Shorea spp) pada hutan tembawang Gindoh. (Tengkawang distribution (Shorea spp) on forest tembawang Gindoh)

Tembawang Gindoh merupakan lokasi tembawang yang terletak di perhuluan dengan kelembaban yang tinggi dan topografi yang akak curam dimana di tepi sungai merupakan tempat pertumbuhan paling disukai tengkawang untuk tumbuh khususnya untuk jenis Shorea macrophylla P.S. Ashton yang tumbuh di semua area tembawang Gindoh. Sebaran tingkat pertumbuhan juga sesuai dengan banyaknya antara jumlah tingkat pohon dengan tingkat anakan menjadikan hutan tembawang Gindoh merupakan tempat tumbuh yang baik bagi jenis Shorea macrophylla P.S. Ashton.

Berdasarkan hasil penelitian secara keseluruhan sebaran tengkawang di hutan tembawang Desa Labian yaitu tersebar secara kelompok, mulai dari tingkat indukan sampai tingkat pertumbuhan anakan semuanya tersebar secara kelompok di setiap hutan tembawang dengan tumbuh berkelompok dekat daerah aliran sungai. Hal ini menunjukan bahwa buah tengkawang yang jatuh ke permukaan tanah dapat tumbuh dengan baik di hutan tembawang Desa Labian. Persebaran masing-masing jenis tengkawang dilihat dari hutan tembawang Desa Labian, Shorea macrophylla P.S. Ashton untuk semua tingkat pertumbuhan tersebar secara mengelompok dimana anakan tidak jauh dari indukannya dan tersebar hampir di sepanjang daerah aliran sungai. Shorea stenoptera Bruck memiliki penyebaran yang mengelompok dan ditemukan hanya di hutan tembawang Kayu Baung dengan anakan juga tersebar secara mengelompok di dekat pohon induk dan 
tumbuh jauh dari daerah aliran sungai. Shorea pinanga Scheff juga tersebar secara berkelompok di hutan tembawang Kayu Baung dan anakan juga tersebar tidak jauh dari pohon induknya dan di temukan berada jauh dari daerah aliran sungai. Shorea seminis Slooten juga tersebar secara mengelompok dengan anakan juga tidak jauh dari pohon induk dan di temukan tumbuh di daerah aliran sungai.

\section{KESIMPULAN}

Berdasarkan hasil penelitian di hutan tembawang desa Labian dapat disimpulkan sebagai berikut :

1. Berdasarkan bentuk tofografi kelerengan tempat tumbuh tengkawang dengan kelerengan ratarata $9-23 \%$ dan ketinggan $40-87$ $\mathrm{M}$ dpl.

2. Jenis tengkawang (Shorea spp) yang ditemukan sebanyak empat jenis yaitu, tengkawang Amat (Shorea macrophylla P.S. Ashton), tengkawang Tukul (Shorea stenoptera Bruck), tengkawang Langgai (Shorea pinanga Scheff) dan tengkawang Breh (Shorea seminis v. Slooten).

3. Shorea macrophylla P.S. Ashton dan Shorea seminis V Slooten tersebar pada topografi landai dengan kemiringan lereng 9-23 \% dengan ketinggian antara $40-87 \mathrm{M}$ dpl.

4. Shorea stenoptera Bruk dan Shorea pinanga Scheff untuk tingkat semai sampai tingkat pohon berdasarkan topografi tersebar secara mengelompok di lereng rata-rata $9 \%$ dengan tumbuh hanya pada ketinggian 60-70 Mdpl dan jauh dari aliran sungai, kedua jenis ini hanya ditemukan di tembawang Kayu Baung.

\section{SARAN}

1. Untuk menjaga keseimbangan tingkat petumbuhan tengkawang perlu adanya perhatian masyarakat untuk tidak memngambil semua buah yang jatuh ke permukaan tanah

2. Berkaitan dengan pemanfaatan dan pembudidayaannya, maka perlu dilakukan penelitian lebih lanjut tentang pohon Plus setiap jenis tengkawang pada lokasi yang sama, sehingga akan membantu dalam upaya pelestarian dan pastinya diharapkan dapat memberikan dampak ekonomi bagi masayarakat sekitar.

\section{DAFTAR PUSTAKA}

Ashton, P.S., 1982. Dipterocarpaceae. In: Van Steenis, C.G.G.J (ed.) Flora Malesiana (9): 237-552.

Indriyanto. 2006. Ekologi hutan. Jakarta :PT. Bumi Kasara

Istomo, Hidayati T. 2010. Studi Potensi dan Penyebaran Tengkawang (Shorea spp.) di Areal IUPHHKHA PT. Intracawood Manufacturing Tarakan, Kalimantan Timur. Jurnal Silviultur Tropika. 01(01):11-17

Nasir AM. 2011. Rencana Pembangunan Jangka Menengah Daerah (RPJMD) Kabupaten Kapuas Hulu.

Nuning SB. 1997. Peluang Minyak Tengkawang untuk Bahan Baku Kosmetika dan Standarisasi 
Produk. Tengkawang Tungkul Kalimantan Barat. Jakarta : Martha Tilaar Group.

Purwaningsih. 2004. Sebaran Ekologi Jenis-Jenis Dipterocarpaceae di Indonesia. Biodiversitas 5(2):8995. UNS Surakarta.

Saridan A, Fernandes A, Noor M. 2013. Sebaran Dan Potensi Pohon Tengkawang di Hutan Penelitian Lebanan, Kalimantan Timur. Jurnal Penelitian Dipterokarpa. 7(2):101-108

Supartini, Fajri M. 2015. Potensi Tengkawang Di kebun Masyarakat Dusun Tem'bak, Sintang, Kalimantan Barat. Jurnal Penelitian Ekosistem Dipterokarpa. 1(1):7-14.

Vebri, O. 2017. Asosiasi Dan Pola Distribusi Tengkawang (Shorea spp) Pada Hutan Tembawang Desa Nanga Yen Kecamatan Hulu Gurung Kabupaten Kapuas Hulu. Jurnal Hutan Lestari. 5(3) : 704 713 